\title{
THE CHLORAEA FROM LIMA, A LITTLE-KNOWN SPECIES BUT DESCRIBED SEVERAL TIMES
}

\author{
Delsy Trujillo ${ }^{1,4} \&$ Diego Paredes-Burneo ${ }^{2,3}$ \\ ${ }^{1}$ Herbario San Marcos (USM), Museo de Historia Natural, Universidad Nacional Mayor de San Marcos, \\ Av. Arenales 1256, Jesús María, Lima, Perú \\ ${ }^{2}$ Laboratorio de Florística, Departamento de Dicotiledóneas, Museo de Historia Natural UNMSM, \\ Av. Arenales 1256, Jesús María, Lima, Perú \\ ${ }^{3}$ Department of Biological Sciences, Louisiana State University, A257 Life Sciences Annex, \\ Baton Rouge, Louisiana 70803, USA \\ ${ }^{4}$ Author for correspondence: delsytrujillo@gmail.com
}

\begin{abstract}
During the botanical expedition carried out in Peru by Ruiz and Pavón, later by Raimondi's explorations and finally by Weberbauer's, specimens of a Chloraea species were collected in localities around Lima and used to describe Chloraea pavonii, C. undulata and C. peruviana. In this study we reviewed original materials, protologues, drawings, additional herbarium specimens and living material to clarify the taxonomic status of $C$. pavonii. A description, illustration, photographs, and distribution of the species are provided. We also point out the morphological features that distinguish C. pavonii from C. densipapillosa and C. septentrionalis. Lectotypes for C. undulata and C. peruviana are here designated.

Resumen. Durante la expedición botánica realizada en el Perú por Ruiz y Pavón, luego por las exploraciones de Raimondi y finalmente por las de Weberbauer, especímenes de una especie de Chloraea fueron colectados en localidades alrededor de Lima y usados para describir Chloraea pavonii, C. undulata y C. peruviana. En este estudio, hemos revisado los protólogos, material original, ilustraciones, material adicional de herbario y material vivo para clarificar el estado taxonómico de C. pavonii. Se presentan una descripción, ilustración, fotografías y distribución de la especie. También señalamos los caracteres morfológicos que permiten distinguir $C$. pavonii de $C$. densipapillosa y C. septentrionalis. Asimismo, se designan los lectotipos para $C$. undulata y C. peruviana.
\end{abstract}

Key Words / Palabras clave: Chloraea, ecosistema de lomas, Lima, Peru, lectotipificación, lectotypification, lomas ecosystem

Introduction. The Lomas formations are a seasonal ecosystem that occur in the desertic lowlands of the western slopes of the Peruvians Andes. Most of its vegetation (mainly herbaceous) flourish during the humid winter season (May/June to September/ October), when the thick fog masses, coming from the Pacific Ocean, are intercepted by foothills near the sea (Dillon et al. 2011). Five orchids species have been recorded for the Lomas formations (Trujillo 2013); among them, the most conspicuous is a Chloraea Lindl. species (Fig. 1). Since specimens of this species were originally collected in the Lomas near Lima city, it is locally known as the "Lima Orchid". Nevertheless, this species is not restricted to Lomas formation, since some populations have been recorded in shrublands and grasslands on slopes at the highlands of the department of Lima, between 2400 and $3100 \mathrm{~m}$ of elevation (Bennett \& Christenson 1998, Schweinfurth 1958).

The nomenclatural history of this species is a sequence of overlooked works and constant redescriptions of the same entity under different names. The first record of this Chloraea in Lomas was during the Royal Expedition to Peru led by Ruiz and Pavón in 1781 (Ruiz 2007). One of the specimens collected in that expedition was used to describe Chloraea pavonii Lindl, but citing the species for Chile (Lindley 1827, 1840). The second record of this species was done by Antonio Raimondi. Thinking that this was the first record of Chloraea for Peru, he described again the 


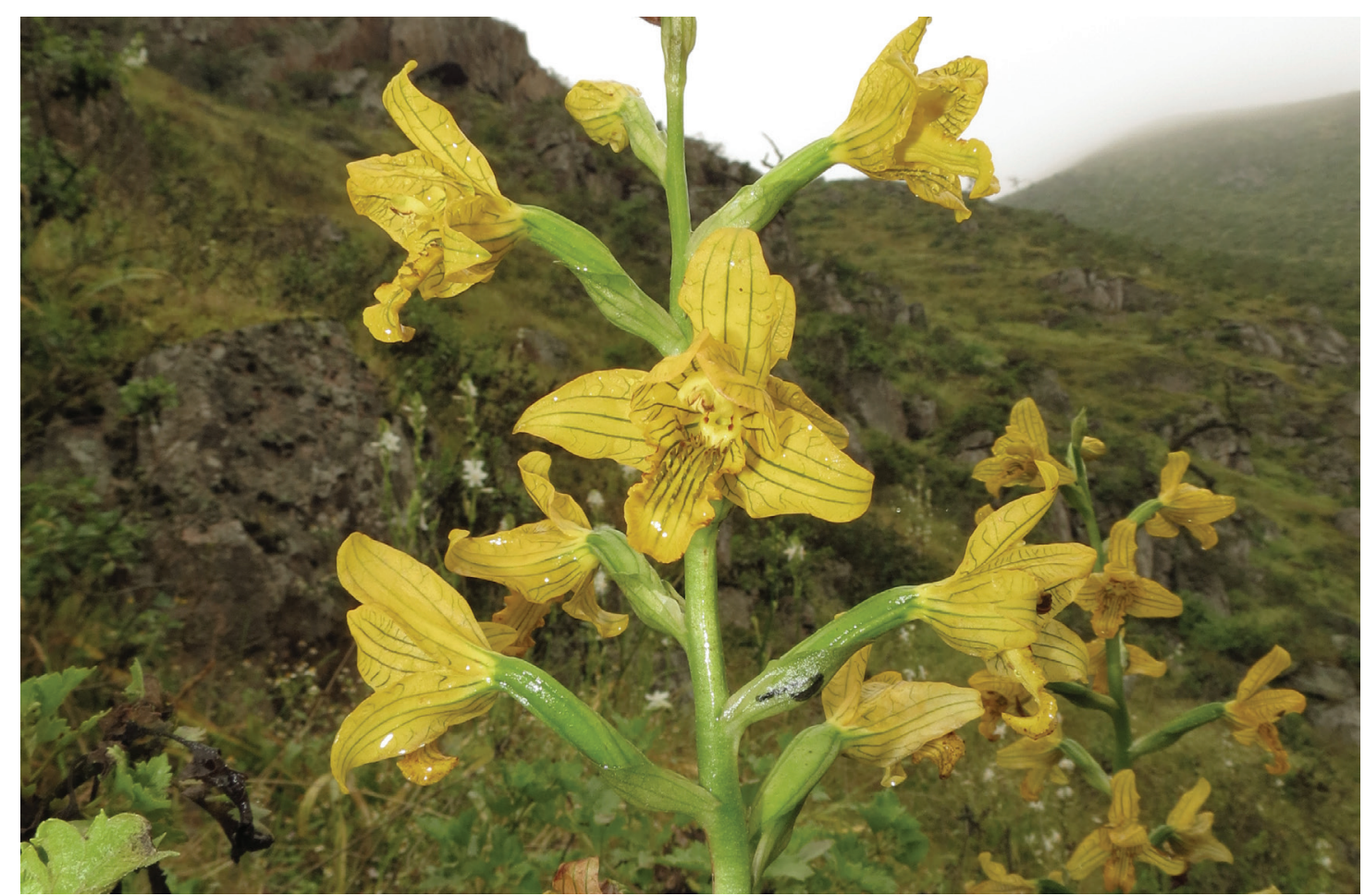

FIGURE 1. Inflorescence of Chloraea pavonii Lindl. Photograph by D. Trujillo.

species under the name Chloraea undulata Raimondi (1857). Later on, based on a specimen collected by August Weberbauer, the species was described again by Kränzlin in 1906 as Chloraea peruviana Kraenzl.

An additional name, but unpublished, was also used by Lindley for this Peruvian orchid: "Chloraea macleanii". The material was collected by John Maclean in Langa (a locality at the highlands of Lima) and sent to Sir William Jackson Hooker at Kew. The herbarium specimens were examined later by Reichenbach, who identified them as Chloraea venosa Rchb.f., a species described for Chile.

Schweinfurth (1958), in his work Orchids of Peru, only cited the species published by Kränzlin: Chloraea peruviana, because he was unaware of Lindley's and Raimondi's works. Some years later, M. N. Correa (1969), in a revision of the genus Chloraea, placed $C$. pavonii as a synonym of Chloraea chrysantha Poepp., and $C$. peruviana as a synonym of $C$. venosa. Correa had access to the specimens collected by Raimondi housed at the herbarium USM, but it seems that she did not know the publication of Raimondi; hence C. undulata was not cited in her publication. The following year, Schweinfurth (1970), in a supplement of the Orchids of Peru, recognized C. undulata and placed C. peruviana as its synonym. In 1998, Garay and Romero-González clarified the identity of $C$. pavonii and placed C. venosa, C. undulata and $C$. peruviana as its synonyms. In subsequent works done by orchid taxonomists, $C$. pavonii is referred as a correct name (Bennett \& Christenson 1998, Pupulin 2012).

Recently, after 50 years without any report of $C$. pavonii from Lomas, Lleellish (2015) recorded the species for Lomas de Asia (located to the south of the department of Lima, central-western portion of Peru); although considering the species as C. undulata and omitting the name $C$. pavonii. In addition, Lleellish indicated that C. undulata [i.e. C. pavonii] occurs in the departments of Cusco, Cajamarca and La Libertad. The misinterpretations of Lleellish then has been followed by other authors; for instance, Leiva and collaborators (2016), who reported C. undulata to the district of Salpo, in La Libertad Department.

After a revision of fresh and herbarium specimens of Chloraea, the present contribution aims to clarify 
the taxonomic status of $C$. pavonii by providing morphological and ecological information of the species and pointing out some morphological characters that can help to distinguish it from the other Chloraea species that occur in Peru.

\section{TAXONOMIC TREATMENT}

Chloraea pavonii Lindl. Gen. Sp. Orchid. Pl. 404. 1840.

Basionym: Asarca speciosa Lindl., Quart. J. Sci. Lit. Arts 1: 52. 1827.

TYPE: "Habitat in Chili, Pavón (olim v. s. sp.)"; "Serapias Gavilú. Pavón in herb. Lambert", Pavón s.n. (holotype: BM-95631) (Fig. 2)1.

Synonyms: Chloraea undulata Raimondi, Elem. Bot.

(Raimondi) 143. 1857.

TYPE: [Peru], Lima, Raimondi s.n. [Raimondi Herbarium sheet 9904, Catalogue No 446a] (lectotype, here designated: USM).

Chloraea peruviana Kraenzl., Bot. Jahrb. Syst. 37(5): 528. 1906.

TYPE: Peru. Amancaes Mountains at Lima, in Loma Formation, $500 \mathrm{~m}$, A. Weberbauer s.n. (holotype: B destroyed, photo at, AMES-38618!. Isotype: HBG-501465, photo seen, designated here as the lectotype).

Terrestrial plant about 40 to $79 \mathrm{~cm}$ high. Roots fascicled, cylindrical and fleshy. Stem stout, leafy. Leaves spirally arranged along the stem (rare compressed like a basal rosette), blade ovate, ovateoblong or oblong-lanceolate, obtuse or acute, amplexicaul, about 6-14 [19] × 2-5 cm (Figure 3A, B). Inflorescence terminal, lax, 11-30 cm long, with 6 to 30 flowers. Floral bracts ovate to lanceolate, acute, slightly longer to shorter than the ovary, green, 1.8-3.9 $\times 0.7-1.8 \mathrm{~cm}$ (decreasing in size towards the apex). Flowers, resupinate, yellow with green reticulate veins (Figures 1, 3C-E). Dorsal sepal elliptic to oblongelliptic, obtuse to sub-acute, with 5 main nerves, 2.8$3.5 \times 0.9-1.6 \mathrm{~cm}$. Lateral sepals elliptic to oblonglanceolate, slightly oblique, obtuse to sub-acute, with 5 to 7 main nerves, $2.9-3.4 \times 1.1-1.5 \mathrm{~cm}$. Petals elliptic-ovate, asymmetric, obtuse-rounded, with 4 main nerves, $2.2-2.8 \times 1.2-1.4 \mathrm{~cm}$. Lip clawed, entire to obscurely 3-lobed, oblong to ovate-oblong, basal part and central disk provided with numerous short flattened keels or falcate keel-like teeth irregularly scattered along the main nerves of the lip, 2.1-2.2 $\times$ $1.2-1.4 \mathrm{~cm}$. Column slender, slightly arcuate, apex with rounded wings, with a pair of nectaries between the column and the labellum, 1.7-1.8 cm long. Stigma triangular. Ovary $2.0-4.5 \mathrm{~cm}$ long (Fig. 4).

Specimens examined.- PERU. Lima. Flo P., cum L., Habitat in Provinciae Limae ad Amancaes et Chancay ad Jequar collibus altis inter saxa [Ruiz \& Pavón s.n.] (MA810745, photo seen). In Jequar Chancay in collibus altis inter saxa in Lima et Amanc alt, Flor P. Jul-Aug, [Ruiz \& Pavón s.n.] (W-78557 Rchb. Orch. 43089, photo seen). Without a precise locality, Flor. P, Jul-Aug, [Ruiz \& Pavón s.n.] (G-105744, photo seen). Without a precise locality, Dombey s.n. (P-369476, photo seen). Grows on almost inaccessible heights between Cerros de San Cristobal and de Amancaes, as well as on rocky slopes of the San Bartolomé, Jul-Aug, Barranca \& Wawra 471 (W-55114, photo seen). Without collection data [dissected flower with a copy of the original drawing on sheet number K-501998], (W-78549 Rchb. Orch. 43091, photo seen). Without collection data [Drawing] (W-78558 Rchb. Orch. 42990, photo seen). Prov. Canta, Limite de los distritos Arahuay-Lachaqui, 2650-2700 m, declive rocoso con vegetación herbácea, 10 Apr 1993, G. Vilcapoma 2212 (USM-278407). Prov. Canta, Lachaqui, arriba del puente Romero en Camino hacia Arahuay, 2750-2900 m, ladera rocosa, 29 Mar 1993, G. Vilcapoma 2420 (USM-278406). Prov. Canta, Collo, camino al paraje de Achupata, 2400 $2500 \mathrm{~m}$, ladera rocosa con predominio de Malvaceas, 16 Apr 2006, G. Vilcapoma 7623 (USM-278405). Prov. Canta, Arahuay, Camino al lado del rio Arahuay, 2550$2650 \mathrm{~m}$, vegetación dominada por Carica candicans "mito", 24 Mar 2008, P. Gonzáles 97 (USM-259386). Prov. Canta, Arahuay, 2600 m, Mar 1994, M. León 391 (MOL). Prov. Canta, Arahuay, 2635 m, 3 Apr 1994, M. León s.n. ex Bennett 6583 (MOL-spirit). [Probably same locality] M. León 393 ex Bennett 6583 (MOL-spirit). Prov. Canta, Arahuay, $2600 \mathrm{~m}$, without collector (MOLspirit). Prov. Cañete, Asia, 514 m, Ecosistema de Lomas,

1 Due to the extraordinary circumstances provoked by the Covid-19 pandemic, direct access to herbarium high resolution images through the curatorial staff has been largely impeded. The figures printed in this paper were therefore obtained from the images made available in the web pages of the concerned herbaria, which are individually acknowledged in the captions as to their copyright. 


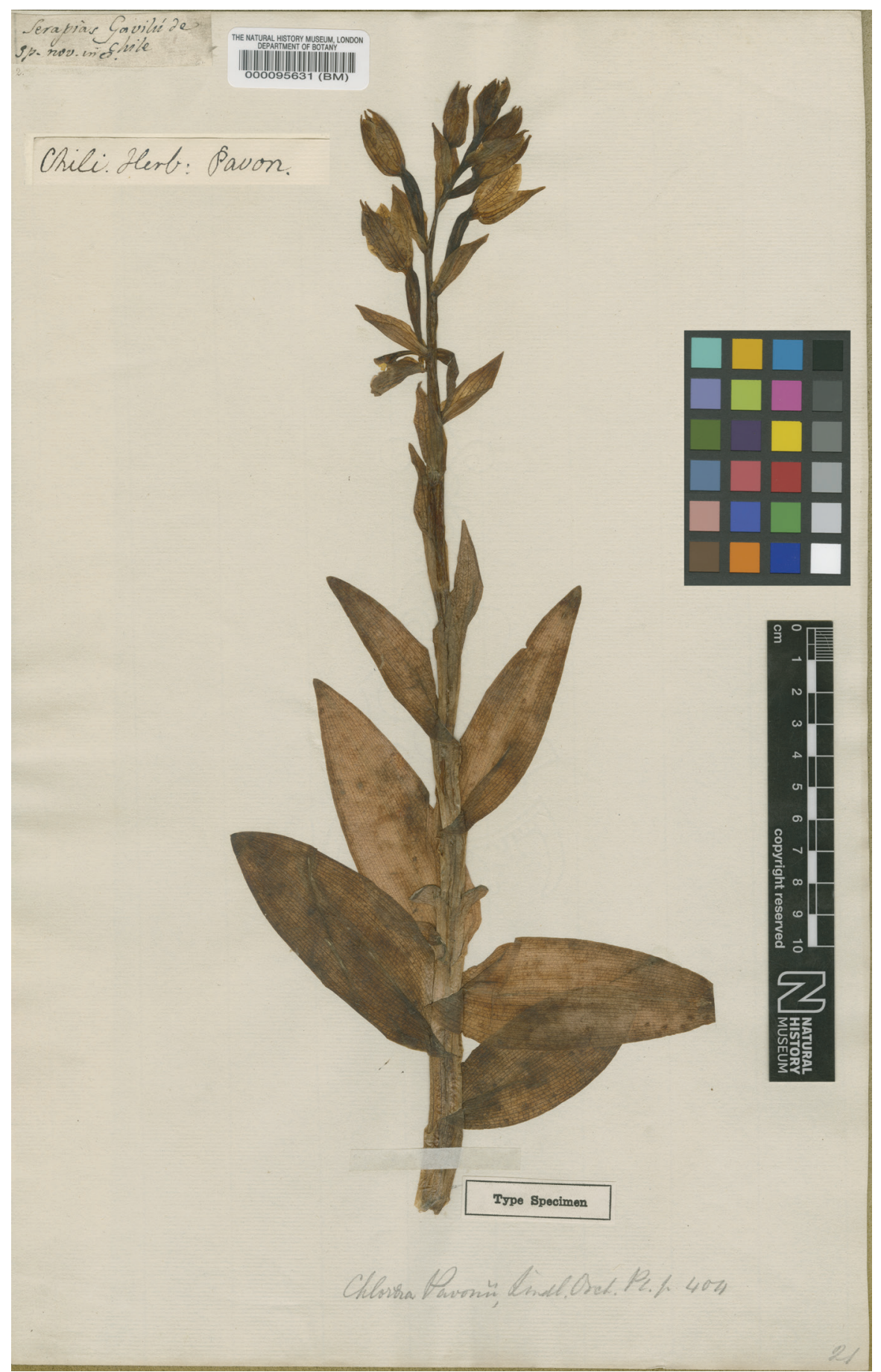

FiguRE 2. Holotype of Chloraea pavonii Lindl. Original collection by H. Ruiz and J. Pavón, hosted at the Natural History Museum, London (BM000095631). Retrieved from the web page of Natural History Museum, Data Portal Specimen Records, filed as Gavilea pavonii. Permanent URL: https://data.nhm.ac.uk/object/298ae096-756e-44e2-bbe1f4345246e02a/1586390400000. Retrieved: 13 Apr 2020 15:27 (GMT). All the rights belong to the Natural History Museum. 


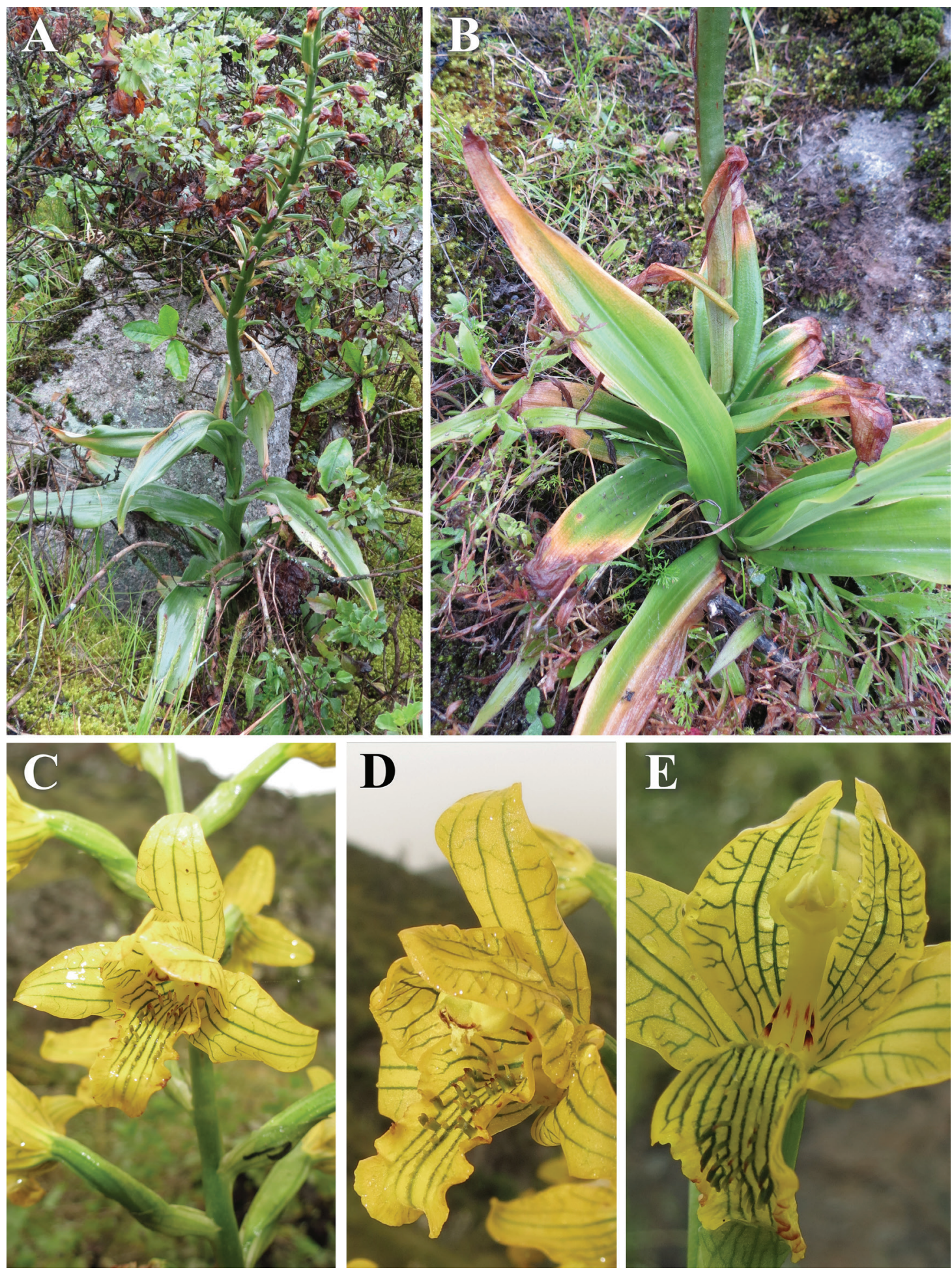

Figure 3. Chloraea pavonii Lindl. A. Habit. B. Leaves. C. Flower, front view. D. Flower, side view E. Flower, showing the column and the lip. Photographs taken in Lomas de Asia (Cañete) by D. Trujillo. 

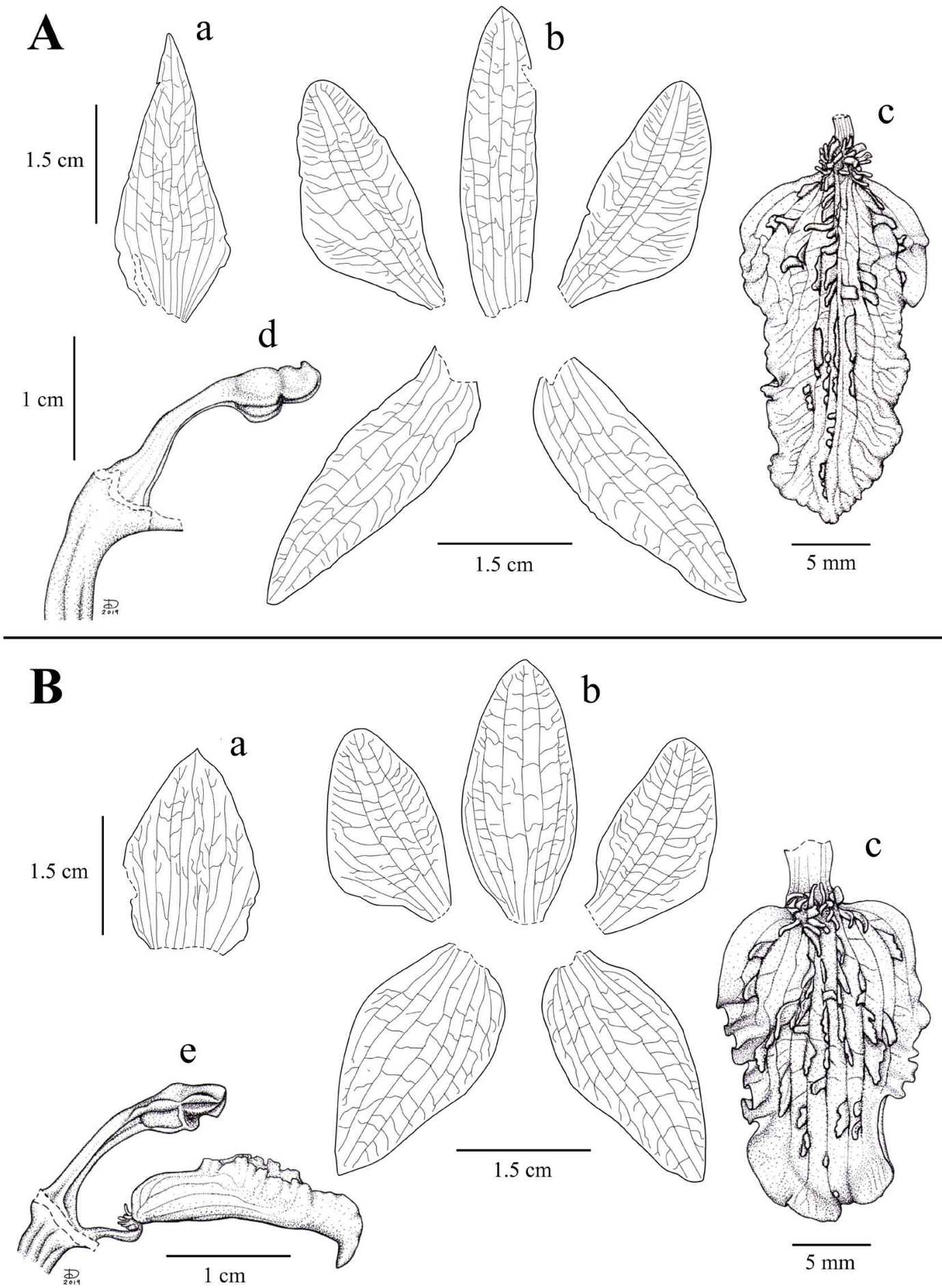

Figure 4. Chloraea pavonii Lindl. A. Flower of a plant from Arahuay-Lachaqui, Canta (G. Vilcapoma 2212, USM-278407).

B. Flower of a plant from Bosque de Zárate, Huarochirí (E. Morón s.n., USM-257683). a. Floral bract. b. Dissected perianth. c. Lip. d. Column. e. Column and lip lateral view. Drawing by D. Trujillo. 
zona media, sobre ladera con afloraciones rocosas, 16 Sep 2017, Paredes \& Reyna 871 (USM). Prov. Chancay [Huaral], Lomas de Chancay, $350 \mathrm{~m}$, hábitat rocoso, en laderas muy inclinada, 24 Set 1952, R. Ferreyra 8748 (USM-165083). Prov. Chancay [Huaral], Lomas de Chancay, $350 \mathrm{~m}$, hábitat rocoso, lomas arcillosas, 24 Set 1952, R. Ferreyra 8748 (USM). Prov. Huarochirí, Langa, 2900 m, 22 Mar 1982, A. Cano et al. 2123 (USM-165081). [Prov. Huarochirí], Langa, Maclean s.n. (K-501996, photo seen.). Same locality, Maclean s.n. (K-501997, photo seen). Same locality, Maclean s.n. (K-501998, photo seen). [Prov. Huarochirí], Langa, [drawing of K-501998], Maclean s.n. (W-78548 Rchb. Orch. 42983, photo seen). Prov. Huarochirí, Matucana, $8000 \mathrm{ft}$, in the moister swales of eastern hillsides, $12 \mathrm{Apr}$ - 3 May 1922, Macbride \& Featherstone. 372 (F-516907, photo seen). Prov. Huarochirí, San Bartolomé, Bosque de Zárate, km 56 Carretera Central, 3100 m, bosque andino, 15 Jun 2012, E. Moron s.n. (USM-257683). Prov. Huarochirí, San Bartolomé, Monte de Zárate, 1400-3550 $\mathrm{m}$, matorral y relicto de bosque dominado por Oreopanax y Myrcianthes entre otros, 24-26 Apr 2009, P. Gonzáles et al. 481 (USM-256794). [Prov. Huarochirí, San Bartolomé], Cerro de San Bartolomeo, Jul 1876, L Savatier 1449 (K501994, photo seen). Prov. Huarochirí, Surco, 2400 m, Apr 1916, N. Esposto s.n. (MOL-8287). Prov. Huarochirí, Surco, cumbre de un cerro, 15 Apr 1920, N. Esposto s.n. (MOL-8286). Prov. Lima, San Jerónimo Uber Amancaes, 600 m, 20 Jun 1920, K. Maisch s.n. (USM-13659). Prov. Lima, alrededores de Lima, A. Raimondi s.n. [Raimondi Herbarium Sheet 9943 Catalogue No 446b] (USM). Prov. Lima, Cerros de Amancaes, cerca a Lima, N. Esposto s.n. [in part] (MOL-8289). Prov. Lima, Cerros de Amancaes, cerca a Lima, Ago 1910, N. Esposto s.n. (MOL-8288). Prov. Lima, Hills around Lima, 1862, W. Nation s.n. (K501995, photo seen). [Prov. Lima,] Lima, cerro Agustino, 490 m, Set 1945, J. Soukup 1625 (LIL-15022, photo seen).

Distribution: Known only from central western slopes of Peru. It has been recorded in five provinces of the department of Lima: Huaral, Canta, Huarochirí, Lima and Cañete, between 350 and $3100 \mathrm{~m}$ of elevation (Fig. 5).

HaBitat AND ECOLOGY: Individuals of this species were found growing in Lomas formation of rocky or stony ground in the desertic lowlands, and montane forest relict, shrublands and grasslands in the highlands. Flowering from March to June in highlands; and from August to September in Lomas formation.

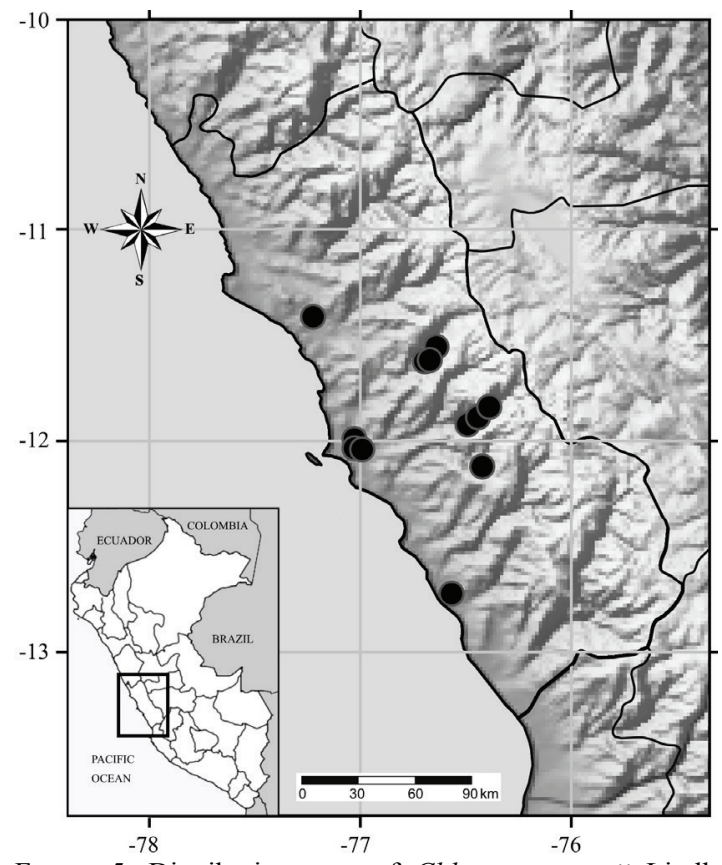

FIGURE 5. Distribution map of Chloraea pavonii Lindl. (black circles) in Peru.

Collection and nOMEnClatural history: The first specimens of Chloraea pavonii were collected by Ruiz and Pavón during the winter of 1781 (July to September), when their expedition carried out a second trip to the Province of Chancay (currently, split into three Provinces: Barranca, Huaura and Huaral). In his diary, regarding to this trip, Ruiz refers: "During this time [we] walked the Hills, Lomas and Valleys of Chancay, Pasamayo, Jequar, Retes and Laral in which [we] described several new plants of which I described the following: [...] Serapias flava, [...]" (Ruiz 2007, p.183, Ms 22). Ruiz also refers that once ended this trip to Chancay, he and Pavón met with Don Toribio Bravo de Castilla, owner of the Hacienda Torreblanca who escorted them to collect plants not only in his property, but also in Lima, at the hills of Amancaes (Ruiz 2007, p.188, Ms 24).

Specimens of $C$. pavonii collected by Ruiz \& Pavón are currently located at the BM, G, MA and W herbaria; a drawing of the species, prepared by Brunete (one of the painters of the expedition) is also conserved at MA (Fig. 6). Specimens housed at G (G-105744, Fig. 7) and MA (MA-810745, Fig. 8) have the original labels of the expedition. These labels bear a short plant description and notes about either the collection 


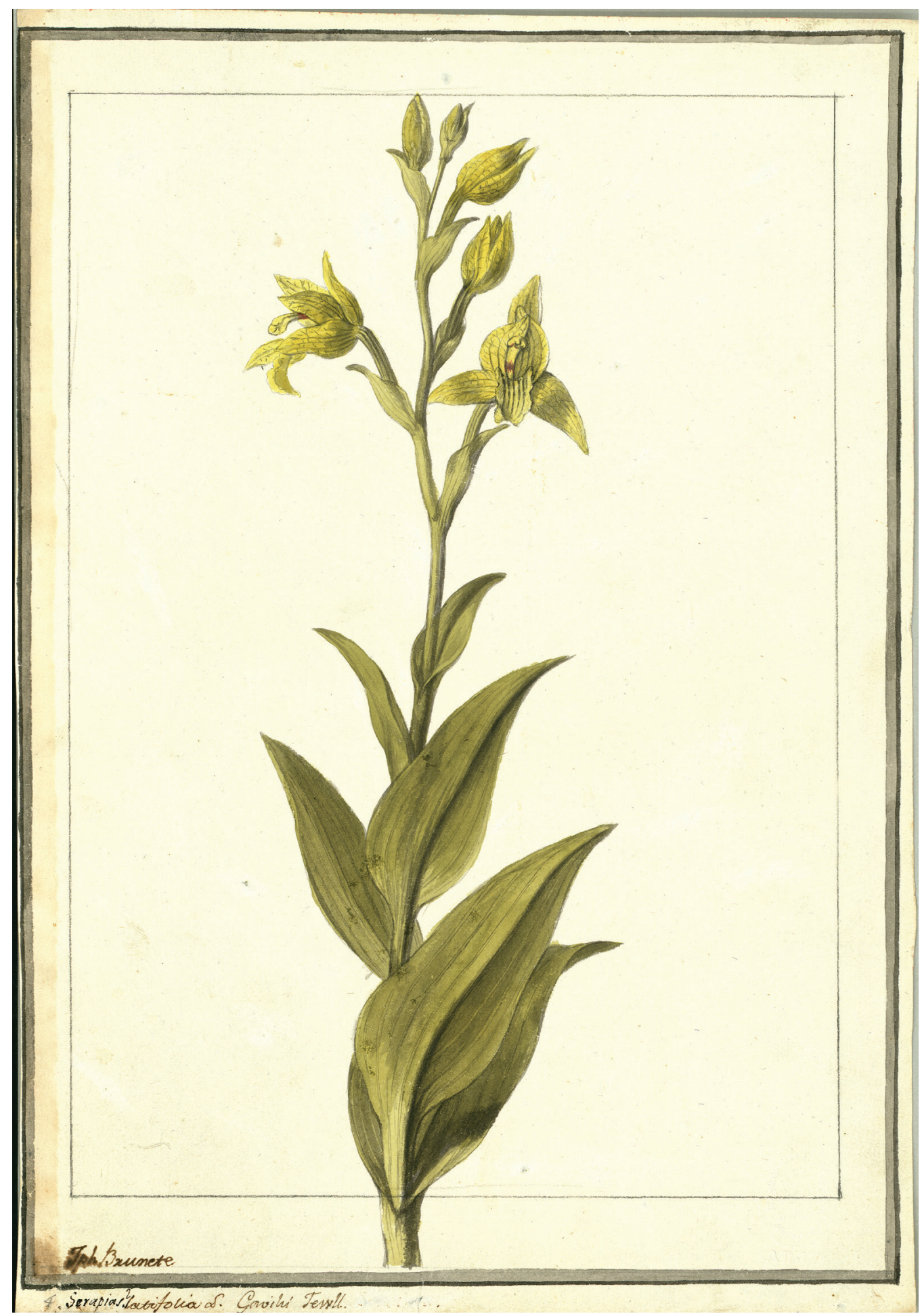

Figure 6. Chloraea pavonii Lindl. AJB, Div. IV, 1318, tempera on paper by J. Brunete. Illustration reproduced from Pupulin (2012: Fig. 10A), in Anales del Jardín Botánico de Madrid. 


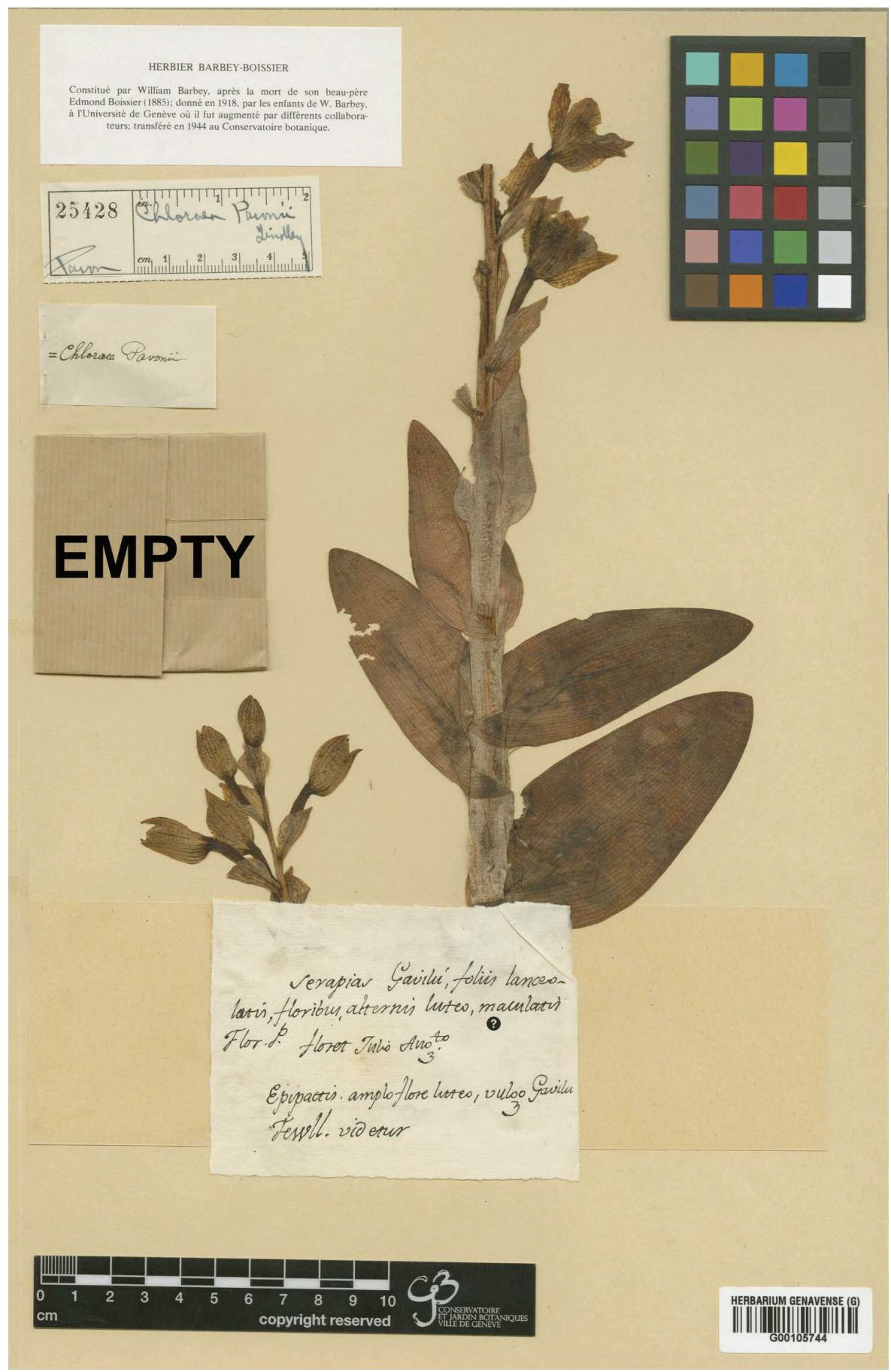

Figure 7. Chloraea pavonii Lindl. Original collection by H. Ruiz and J. Pavón, hosted at the Conservatoire et Jardin botaniques de la Ville de Genève (G00105744 - n SIB 141746/1). Retrieved from the web page of the Conservatoire \& Jardin botaniques de la Ville de Genève, Catalogue des herbiers de Genève (CHG), filed as Chloraea pavonii. URL: http://www.ville-ge.ch/musinfo/bd/cjb/chg/adetail.php?id=131865\&lang. Retrieved: 14 Apr 2020. All the rights belong to Conservatoire et Jardin botaniques de la Ville de Genève. 


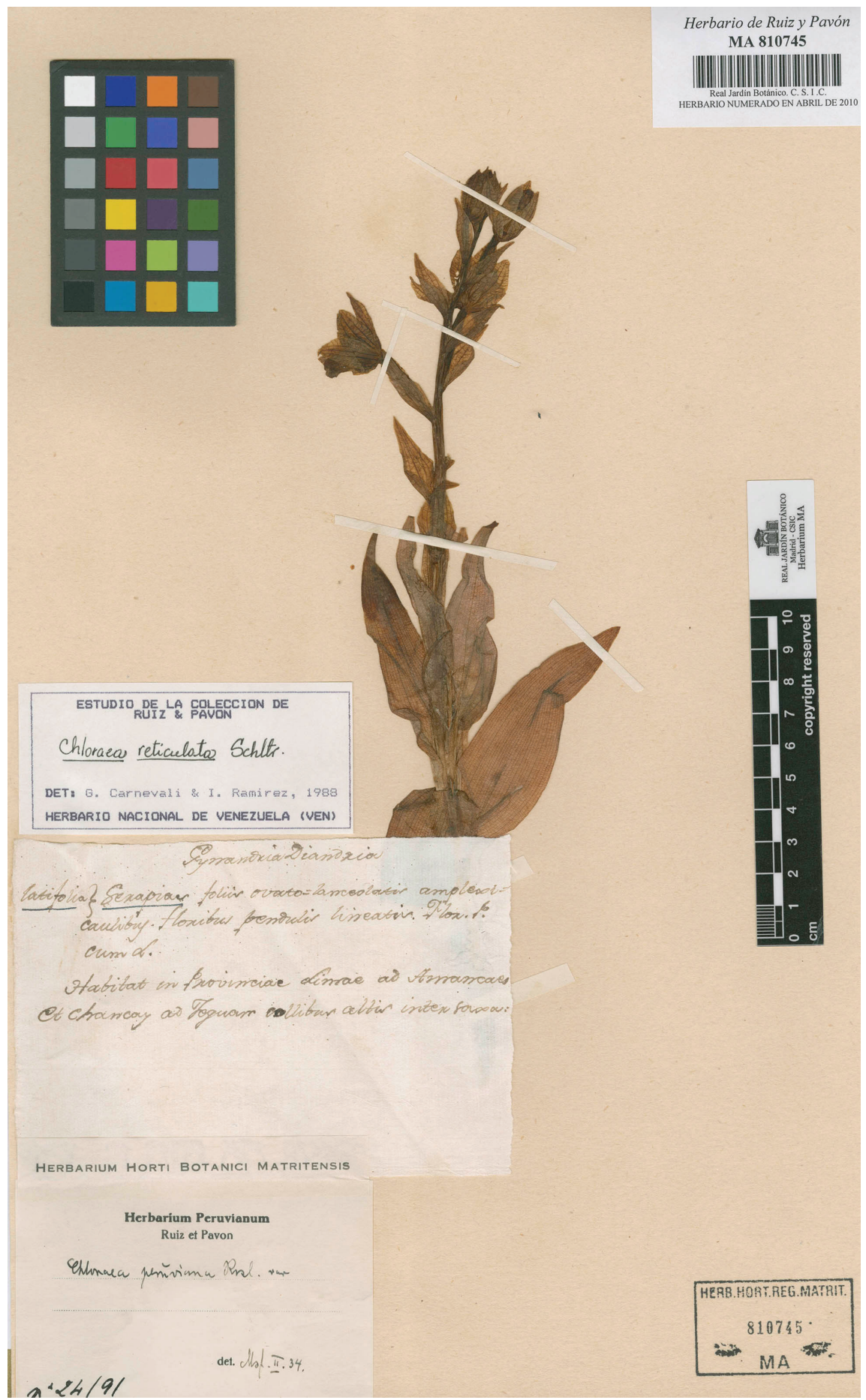

FiguRe 8. Chloraea pavonii Lindl. Original collection by H. Ruiz and J. Pavón, hosted at the Herbario del Real Jardín Botánico (MA-01-00810745). Retrieved from the web page of Real Jardín Botánico, filed as Chloraea peruviana. URL: http://colecciones.rjb.csic.es/\#card.php?id_name=22431/ Retrieved: 13 Apr 2020. All the rights belong to the Real Jardín Botánico-CSIC. 
localities or the flowering time. The label of the specimen at MA states the collection places: "Flor. P. Habitat in Provinciae Limae ad Amancaes et Chancay ad Jequar collibus altis inter saxa"; and the label of the specimen at G states the flowering time: "Flor. P. floret Julio-Augto". The collection data of these herbarium specimens agree with what Ruiz wrote in his diary. The specimen housed at $\mathrm{W}$ belongs to the Reichenbach Herbarium (W-78557 Rchb. Orch. 43089, photo seen) and has two labels with his handwriting. One label bears similar locality data to that stated on the label of the specimen housed at MA. The second label bears the same plant description and flowering data stated on the label of the specimen housed at $\mathrm{G}$.

The specimen housed at BM (BM-95631, Fig. 2) has two small labels that bears the following data: "Serapias gavilú de Chile sp. nov. ined.", in Ruiz' handwriting, and "Chili Herb: Pavon", by Pavón's hand. The specimens of $C$. pavonii currently located at $B M$ and $G$ are the samples that originally were acquired by Lambert from Pavón (Miller 1970). Garay and Romero-González (1998) and Pupulin (2012) designated the specimen at $G$ as the holotype. However, the specimen used by Lindley to describe Asarca speciosa Lindl, later transferred to C. pavonii is the one housed at BM because the data on the labels agree with the protologue; therefore this specimen represents the holotype and not the one at G. Still it is uncertain whether the specimen at BM was collected in Chile (as the label indicates) or in Peru. As no additional collections of $C$. pavonii have been recorded from Chile (since the species was described), and being all the records exclusively known from Peru (even the specimens at MA and G indicate: "Flor P"), then it seems that Ruiz could have made a mistake annotating the specimen as coming from Chile.

There is an additional specimen of $C$. pavonii housed at P (P-369476, photo seen); however, this specimen has a label of Dombey, who was the third botanist of the Royal Expedition. Since Dombey was in the Callao Port taking some sea measurements by the Viceroy's order (Ruiz 2007, p.182, Ms. 22), he did not take part of the second trip to the Province of Chancay. Hence, it seems that the specimen of $C$. pavonii at $\mathrm{P}$ does not belong to the same gathering of Ruiz and Pavón in Chancay-Amancaes. Dombey could have collected it exploring alone the hills around Lima.
Chloraea undulata was described by Antonio Raimondi in his book: "Elementos de botánica aplicada a la medicina y a la industria" (1857: 143). Raimondi was professor of Natural History in the Medicine School of Lima between 1856 to 1873 (Quesada 1921). He published this book with the purpose to provide his students of medicine the bases of the Botany by citing species that they could observe around Lima. This way, indicating that an orchid inhabits some hills near Lima, Raimondi described C. undulata. In 1878, Miguel Colunga, a Raimondi's disciple and friend, published two volumes of the book "Lecciones de botánica". In the second volume (p.187), Colunga included the description of $C$. undulata but referring that Raimondi was the first who described the species.

The publication of Raimondi, as well as the one of Colunga, had a limited distribution; therefore, the description of $C$. undulata was unknown to many botanists. Schweinfurth (1970) only had access to Colunga's publication, but not to that by Raimondi; consequently, Schweinfurth cited the book of Colunga as the original publication of $C$. undulata, but referring to it as "Text Book": "Chloraea undulata Raimondi ex Colunga, Text Book. Bot. 2:187.1878”.

When Garay and Romero-González (1998) clarified the identity of C. pavonii, they pointed out that a material of Chloraea collected by Raimondi housed at $\mathrm{W}$ was the holotype of $C$. undulata, However, that material (W-55114, photo seen) was not collected by Raimondi but by Barranca and Wawra in 1871 during the short stay of Wawra in Lima, after his expedition to the Asian continent on board of the frigate Donau (Wawra 1873).

Two Chloraea specimens from Lima, determined as C. venosa by N. Correa, are kept in the Raimondi collection at the herbarium San Marcos (USM); they have the Raimondi Herbarium Sheet Number 9904 and 9943 (Catalogue No 446a and 466b, respectively). The specimen 9943 is still mounted on the old herbarium sheet that has a letterhead that indicate "Herbario Raymondi". On the herbarium sheet a label indicates "No. 9943 Chloraea peruviana Krzl [Kränzlin]”, which is the determination label sent by the herbarium of the Botanic Garden and Botanical Museum Berlin (BGBM) that had the Raimondi collection as a loan in 1926 (Anonymous 1939, 1940). The specimen 9904, was removed from its original herbarium sheet and 


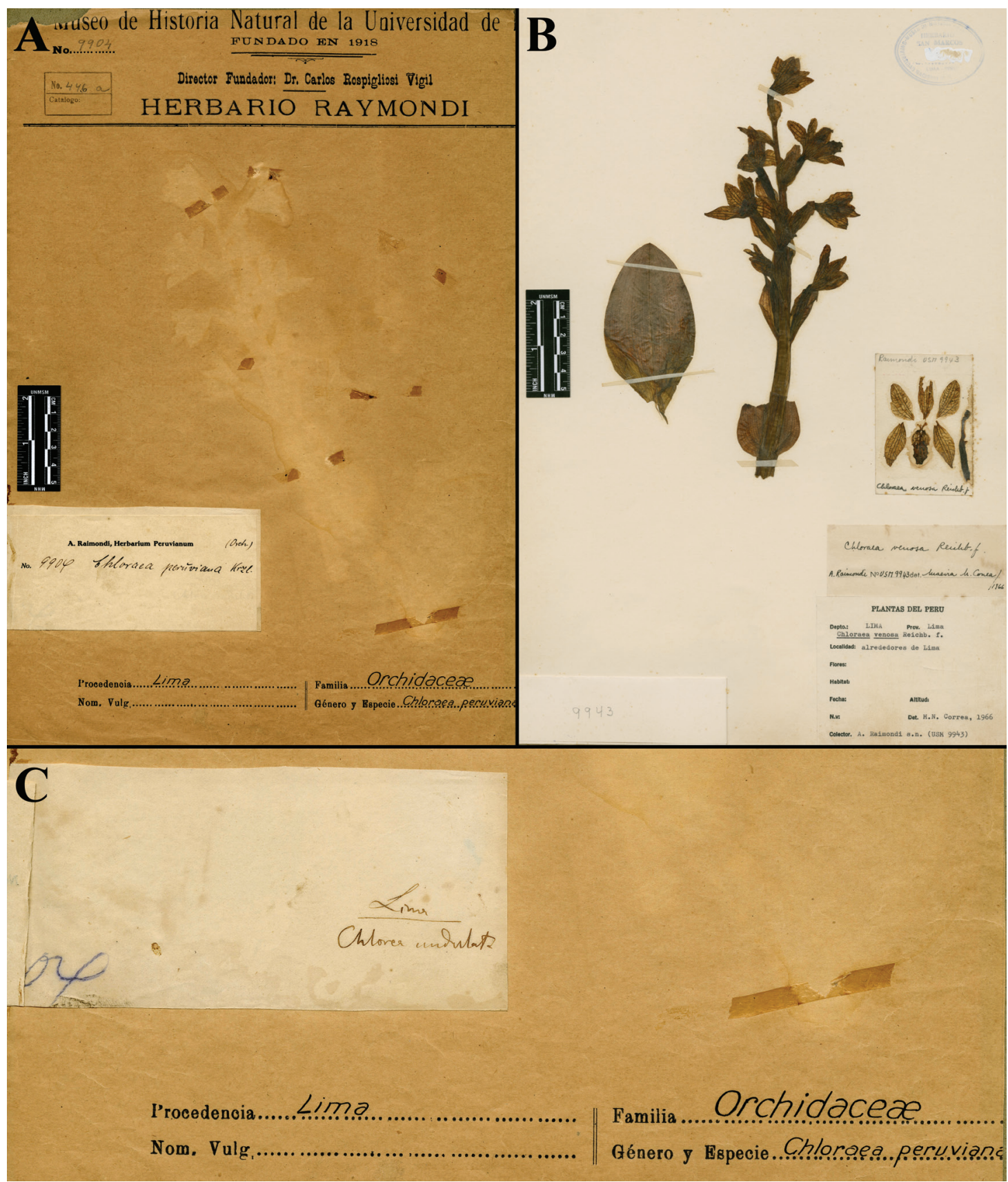

FiguRE 9. Lectotype of Chloraea undulata (=Chloraea pavonii). A. Raimondi Herbarium Sheet Number 9904 at USM, original herbarium sheet from where the specimen was removed. B. Herbarium specimen removed from the Raimondi Herbarium Sheet Number 9904 and mounted in a new sheet with a new label. C. Original label (the second one) with the Raimondi's handwriting glued on the Raimondi Herbarium Sheet Number 9904.

mounted mirroring the original position on a new sheet with a new label; on this new label the number 9943 was wrote instead of 9904 (Fig. 9). On the original herbarium sheet of 9904 two labels are still glued, one covering the other. One is the determination label sent by the herbarium of BGBM which indicates: "No 
9904 Chloraea peruviana Krzl” (Fig. 9A). The second label bears, in Raimondi's handwriting, the following note: "Lima Chloraea undulata" (Fig. 9C). Both specimens (9904 and 9943) are the original material of C. undulata, but only the specimen 9904 has the handwriting of Raimondi; therefore, this one is here designated as lectotype (Shenzhen Code Art. 9.3, 9.12 ICN, Turland et al. 2018).

Lleellish (2015) in his notes on the "Lima Orchid" indicated that Raimondi's specimen: "registro 739 USM" was collected in Lomas near Lima and used to described C. undulata. The specimen that Lleellish indicates - with the Raimondi Herbarium Sheet No 739-USM (=Raimondi 343) - was not collected in Lima but in Quebrada de Chao, La Libertad Department, as indicates the collection data on the label: "343 Chloraea / Bajada por el camino del peñon entre Uningambal y Palmabal, Quebrada de Chao. Mayo 1868 / Flores Amarillo-verdosas". This specimen could be referred to C. septentrionalis M.N.Correa (see below); but the bad condition of the single flower in the specimen prevents its correct determination.

Additional specimens of $C$. pavonii are housed at K under the name "Chloraea macleanii": K-501996 (photo seen), K-501997 (photo seen) and K-501998 (photo seen). These specimens were collected by John Maclean in Langa (Prov. Huarochirí, Lima) and sent to Sir William Jackson Hooker between 1832 to 1854 (Desmond 1994). Lindley determined the Maclean material as C. macleanii but it was never published; probably because Reichenbach had access to that material in 1856 and determined it as C. venosa (see date annotated on a drawing glued at the sheet K-501998). Chloraea venosa was described by Reichenbach based on material from Chile, but without collector data (Reichenbach 1849). At the Reichenbach herbarium at $\mathrm{W}$ are housed two sheets with drawings based on the Maclean specimen K-501998; one bears a drawing of the inflorescence (W-78548, photo seen) and the other bears drawings of a flower and a dissected flower (W-78549, photo seen). The sheet W-78549 has been misinterpreted as type of C. venosa by Correa (1969)

Conservation status.- Chloraea pavonii is endemic to the western slope of the central Peruvian Andes. It is known from eleven locations in the department of Lima, five in the desertic lowlands and six in the highlands. For the populations that occur in the lowlands, the main threats are urban sprawl and overgrazing; three localities: Cerro El Agustino, Cerro San Cristobal and Lomas de Amancaes are today in the middle of the Lima city (capital city of Peru) and the species is considered extinct there. In Lomas de Asia, where the species was recently reported (Lleellish 2015), 18 individuals have been recorded between 2016 and 2018 (D. ParedesBurneo, pers. obs.); the habitat of this population is being managed and protected by local people. The population that inhabits the scrubland and forest relict in the highlands is scant (P. Gonzáles, pers. comm. 2019), the main threats for these populations being habitat loss and degradation due the conversion of land for agriculture and overgrazing, and flowers harvest by the inhabitants (P. Gonzáles pers. comm. 2019). One locality, Zona Reservada Bosque de Zárate is a protected area and it is inferred that will give the adequate protection to the habitat in that area. Based on the eleven known locations, the extent of occurrence estimated by GeoCat is $6791.78 \mathrm{~km}^{2}$, but the area of occupancy is estimated at only $60 \mathrm{~km}^{2}$ (Bachman et al. 2011). The extent of suitable habitat has decreased in the last 70 years; and at present it is thought that the species occurs in eight locations. Therefore, C. pavonii is assessed as Vulnerable based on IUCN criteria B1 and B2 (VU, B1ab(i.iii) + B2ab(ii, iv)) (IUCN 2019).

\section{Comments on other Peruvian Chloraea species}

Chloraea septentrionalis occurs in northwestern Peru, in the departments of Cajamarca and La Libertad (Roque \& León 2006, Trujillo 2012). Some specimens of this species have been erroneously determined as $C$. pavonii (or as its synonym $C$. undulata); for instance, Leiva 526 (HUT-28175!) (Leiva et al. 2016). Both species display yellow flowers with green nerves; however $C$. septentrionalis can be distinguished from $C$. pavonii by its elongate stigma ( $v s$. triangular stigma), 3-lobed lip densely covered by fleshy long warts ( $v s$. entire to obscurely 3-lobed lip provided with numerous short flattened keels or falcate keel-like teeth), and elliptic petals with 5 to 7 main nerves (vs. elliptic-ovate, with 4 main nerves) (Fig. 4, 10, 11). 

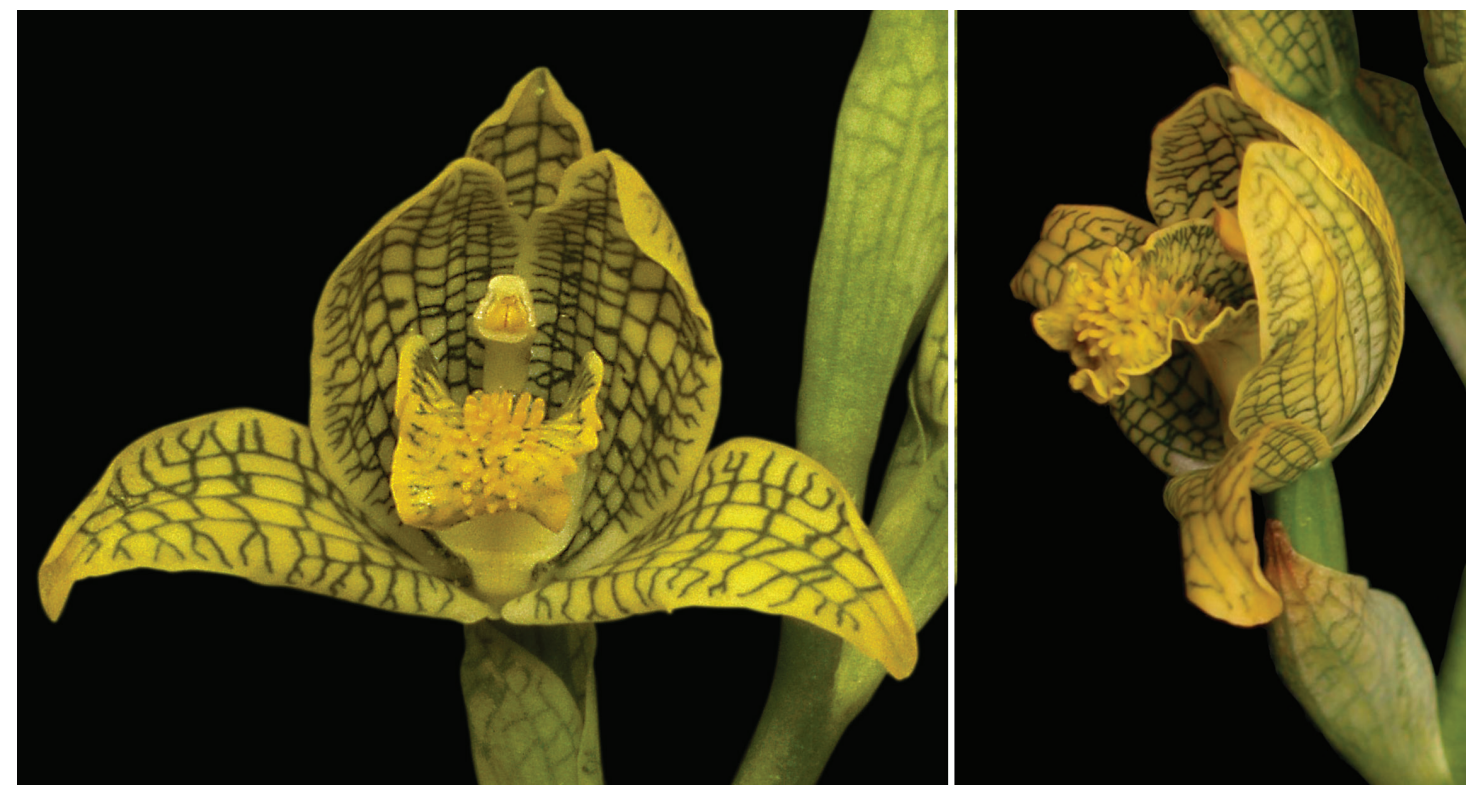

Figure 10. Chloraea septentrionalis. A - Flower, front view. B - Flower, side view. Photographs by D. Trujillo.

Franquemont et al. 1990 recorded C. pavonii (as C. undulata) for the department of Cusco (South Peru) based on the examination of the specimen King 240 (F-1901370, photo seen). However, the floral features of the specimen agree with Chloraea densipapillosa C. Schweinf. This species displays a rather dense inflorescence with yellow flower without green nerves, lip markedly recurved, 3-lobed, pandurate, disc fleshy and covered by a dense pustulate ridges (Fig. 12).
ACKNOWLEDGMENTS. We thank the staff and curators of $\mathrm{K}$, LIL, MOL, USM, and $\mathrm{W}$ for allowing access to their collections. We also thank Paul Gonzáles for providing critical information of C. pavonii, to José Edquén for providing photographs of Chloraea densipapillosa. We would also like to thank the authorities of the "Proyecto Lomas de Asia", period 2017, especially to Iván Reyna, for supporting the observations of C. pavonii in the field. Author Paredes-Burneo is also grateful with the Peruvian Ministerio de Agricultura for granting a collection permit ( ${ }^{\circ}$ 426-2017-SERFOR-DGGSPFFS). We also thank anonymous reviewers for their comments and improvements of the manuscript.

\section{LITERATURE CITED}

Anonymous. (1939). El Herbario Raimondi. Boletín del Museo de Historia Natural Javier Prado, 3(10), 27-46.

Anonymous. (1940). El Herbario Raimondi. Boletín del Museo de Historia Natural Javier Prado, 4(12), 51-62.

Bachman, S., Moat, J., Hill, A. W., de la Torre, J. \& Scott, B. (2011). Supporting Red List threat assessments with GeoCAT: geospatial conservation assessment tool. In: V. Smit \& L. Penev (Eds.). e-Infrastructures for data publishing in biodiversity science. ZooKeys 150, 117126. (Version BETA).

Bennett, D. E. \&. Christenson, E. A. (1998). Icones Orchidacearum Peruviarum, (Plates. 401-600). Lima: Ed. A. Pastorelli de Bennett.
Correa, M. N. (1969). Chloraea, género sudamericano de Orchidaceae. Darwiniana, 15(3-4), 374-500.

Colunga, M. F. (1878). Lecciones de botánica. Tomo II. Lima: Imprenta del Estado.

Desmond, E. (1994). Dictionary of British and Irish botanists and horticulturists including plant collector, flower painters and garden designers. London: Taylor \& Francis Ltd and The Natural History Museum.

Dillon, M., Leiva, S., Zapata, M., Lezama, P. \& Quipuscoa, V. (2011). Floristic checklist of the Peruvian Lomas formations. Arnaldoa, 18(1), 7-32.

Franquemont, C., Plowman, T. C., Franquemont, E., King, S. R., Niezgoda, C. J., Davis, E. W. \& Sperling, C. 

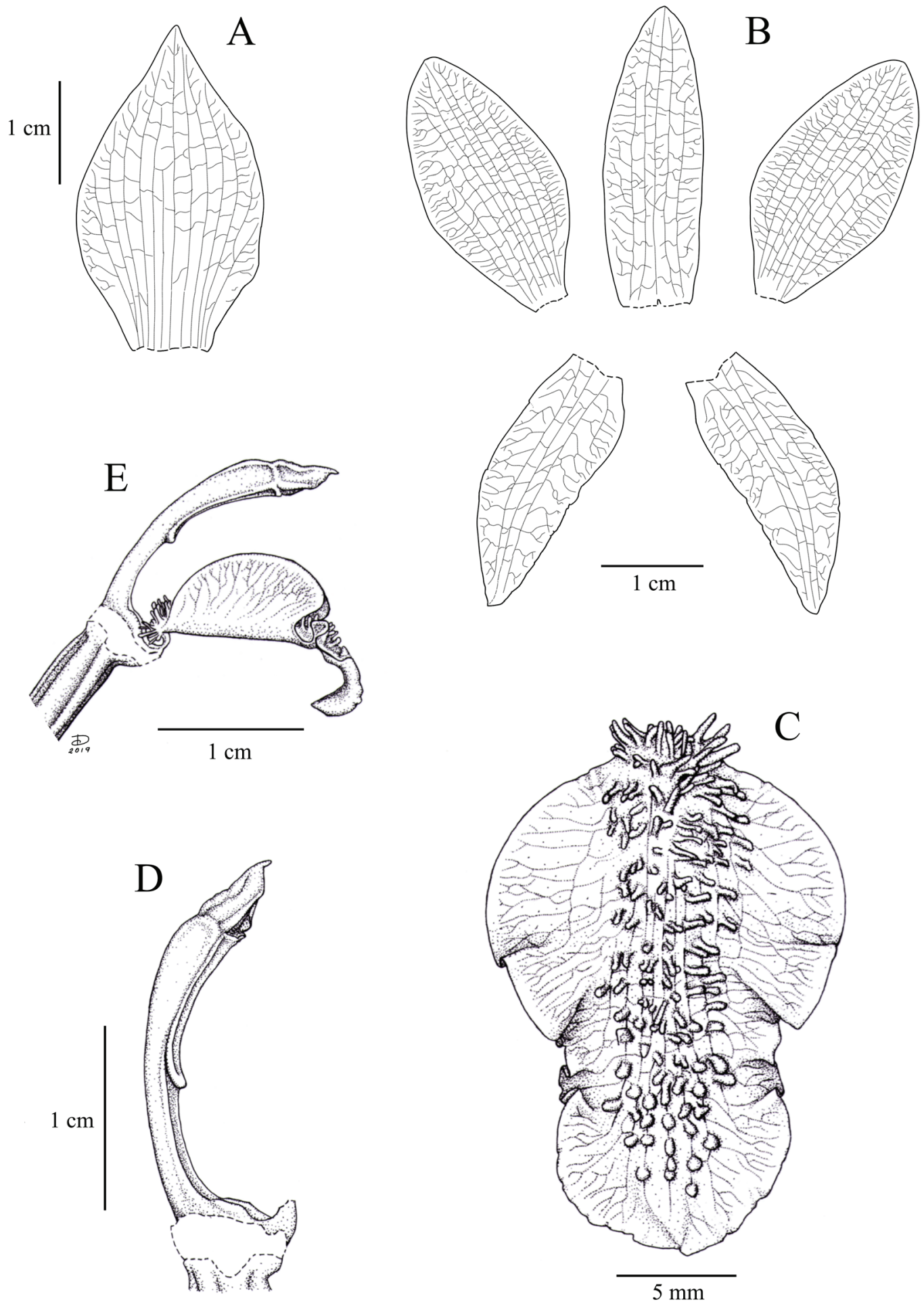

Figure 11. Chloraea septentrionalis. A. Floral bract. B. Dissected perianth. C. Lip. D. Column. E. Column and lip lateral view. Drawing by D. Trujillo based on Trujillo 213. 
R. (1990). The ethnobotany of Chinchero, an Andean community in southern Peru. Fieldiana, Botany, New Series, 24, 1-126.

Garay, L. A. \& Romero-González, G. A. (1998). Schedulae Orchidum. Harvard Papers in Botany, 3(1), 53-62.

IUCN. (2019). Guidelines for Using the IUCN Red List Categories and Criteria. Version 14. Prepared by the Standards and Petitions Committee. Retrieved from http://www.iucnredlist.org/documents/RedListGuidelines.pdf.

Kränzlin, F. (1906). Orchidaceae andinae, imprimis peruvianae Weberbauerianae. IV. Botanische Jahrbücher für Systematik, Pflanzengeschichte und Pflanzengeographie, 37, 520-528.

Leiva, S., Rodríguez, E., Paredes, Y. \& Campos J. (2016). Orchidaceae Juss. que habitan en el distrito Salpo provincia Otuzco, región La Libertad, Perú. Arnaldoa, 23(2), 587-608. http://doi.org/10.22497/ arnaldoa.232.23211.

Lindley, J. (1827). Remarks upon the orchideous plants of Chile. Quarterly Journal of Science, Literature, and the Arts, 1, 43-54.

Lindley, J. (1840). The genera and species of orchidaceous plants. London: J. Ridgways.

Lleellish, M. (2015). Notas sobre Chloraea undulata "Orquídea de Lima" y su registro en las lomas de Asia, Cañete, Perú. Revista Peruana de Biología, 22(3), 309-314.

Miller, H. S. (1970). The herbarium of Aylmer Bourke Lambert: notes on its acquisition, dispersal, and present whereabouts. Taxon, 19(4), 489-553.

Quesada, F. (1921). Las ciencias biológicas. Mercurio Peruano, Revista Mensual de Ciencias Sociales y Letras, 6, 416-430.

Pupulin, F. (2012). The Orchidaceae of Ruiz \& Pavón's "Flora Peruviana et Chilensis". A taxonomic study. I. Anales del Jardín Botánico de Madrid, 69(1), 21-79.

Raimondi, A. (1857). Elementos de botánica aplicada a la medicina y a la industria en los cuales se trata especialmente de las plantas del Perú. Primera parte. Lima: Mariano Murga.

Reichenbach, H. G. (1849). Orchidiographische Beiträge. Linnaea, 22, 859-867.

Roque, J. \& León, B. (2006). Orchidaceae endémicas del Perú. Revista Peruana de Biología, 13(2), 759-878.

Ruiz, H. (2007). Relación del viaje hecho a los reinos de Perú $y$ Chile por los botánicos y dibujantes enviados por el Rey para aquella expedición, extractada de los diarios por el orden que llevó en éstos su autor. Introdución, transcripción y notas de Raúl Rodríguez Nozal y Antonio González Bueno. Madrid: Los Libros de la Catarata.

Schweinfurth, C. (1958). Orchidaceae, Orchids of Peru. Fieldiana, Botany, 30(1), 1-260.

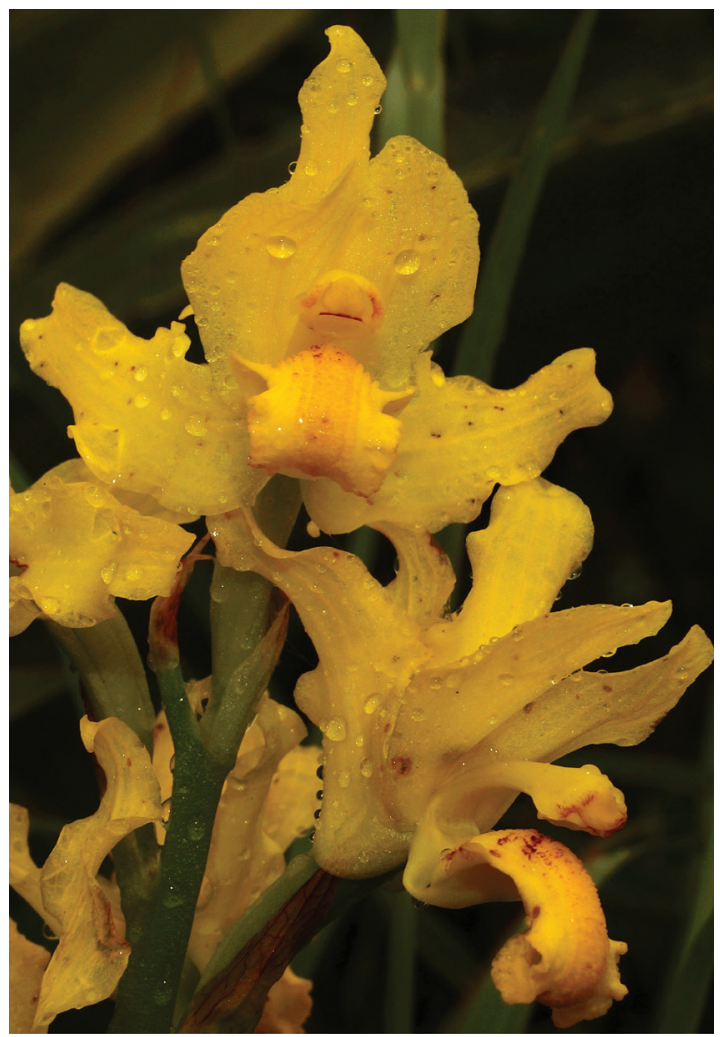

Figure 12. Flowers of Chloraea densipapillosa C.Schweinf. Photograph by J. Edquén.

Schweinfurth, C. (1970). First supplement to the Orchids of Peru. Fieldiana, Botany, 33, 1-85.

Trujillo, D. (2012). High Andean orchids of Peru. Orchid Review, 120, 162-174.

Trujillo, D. (2013). Diversidad de orquídeas de las diferentes formaciones vegetales de los andes peruanos. Lankesteriana, 13(1-2), 103-111.

Turland, N. J., Wiersema, J. H., Barrie, F. R., Greuter, W., Hawksworth, D. L., Herendeen, P. S., Knapp, S., Kusber, W.-H., Li, D.-Z., Marhold, K., May, T. W., McNeill, J., Monro, A. M., Prado, J., Price, M. J. \& Smith, G. F. (Eds.) (2018). International Code of Nomenclature for algae, fungi, and plants (Shenzhen Code) adopted by the Nineteenth International Botanical Congress Shenzhen, China, July 2017. Regnum Vegetabile 159. Glashütten: Koeltz Botanical Books. DOI https://doi. org/10.12705/Code.2018

Wawra, H. (1873). Skizzen von der Erdumseglung S. M. Fregatte "Donau" (Schluss). Österreichische Botanische Zeitschrift, 23(3), 94-99. Retrieved from http://www.jstor.org/stable/43804424. 